\title{
Three-Dimensional Analysis of Bank Profit with the Development of Regulatory Restrictions: Evidence from Egypt
}

\author{
Ashraf Helmy ${ }^{1} \&$ Osama Wagdi ${ }^{2}$ \\ ${ }^{1}$ Ph.D. (Economics), Associate Professor of Economics, Faculty of Economics and International Trade, Egyptian \\ Chinese University, Cairo, Egypt. E-mail: ashraflagoon@gmail.com \\ ${ }^{2}$ Ph.D. (Finance), Faculty of Commerce, Ain Shams University; Lecturer of Finance, Financial Institutions \\ Department, Faculty of Management, MTI University, Cairo, Egypt. E-mail: osamawagdi_ta@yahoo.com \\ Correspondence: Osama Wagdi, Ph.D. (Finance), Faculty of Commerce, Ain Shams University; Lecturer of \\ Finance, Financial Institutions Department, Faculty of Management, MTI University, Cairo, Egypt. Tel: \\ 002-012-488-6966. E-mail: osamawagdi_ta@yahoo.com
}

Received: December 30, 2018

Accepted: February 4, 2019

Online Published: February 15, 2019

doi:10.5539/ijef.v11n3p12

URL: https://doi.org/10.5539/ijef.v11n3p12

\begin{abstract}
This study experienced the effect of different regulatory restrictions and macroeconomic status on banks' profit in Egypt. The study used factor analysis and event study techniques on data that covered the time period from 2003 to 2016 for banking sector as a whole and individual bank unit using a sample of 13 bank units in Egypt; in addition, the study experienced the performance of common stocks of the bank units in the sample. The study found that the development of regulatory restrictions has a positive effect on the profitability of the banking sector; however, due to the differentiated characteristics of individual bank units, this effect was dissimilar for different bank units in the sample. Finally, the study concluded that if individual bank units play their development role in the economy, they will be able to meet the new set of regulatory restrictions and at the same time achieve high rates of return on their assets.
\end{abstract}

Keywords: regulatory restrictions, bank profitability, basel committee, capital adequacy, Egypt

\section{General Framework of the Research}

\subsection{Introduction}

The 2008 global financial crisis revealed a number of dynamic relationships between economic and financial variables that result in multiple default cases in the banking sector. These defaults or failures are attributed to high levels of financial leverage, incompatible due periods of assets and liabilities, inadequate liquidity against financial obligations, asymmetric information, and rapid changes in financial position's items which represents, by itself, an obstacle in the process of proper evaluation of banks' financial positions (Baba et al., 2009; Fernando et al., 2012; Johnson \& Mamun et al., 2012; Prügl, 2012; Dumontaux \& Pop, 2013; Gambacorta \& Paolo, 2014; Kim \& Song, 2017).

In this context, the importance of capital adequacy concept and its development has been increased to support the financial positions of commercial banks; this was a main pillar ratified by Basel I in July 1988 which obliged banks to retain not less than $8 \%$ of total assets value to meet credit risk. In 2001, as a result of Basel I failure in determining a minimum capital adequacy to meet different risks incurred by banks, Basel II standards have been issued to develop capital adequacy concept, ensure the quality of controlling systems and maintain market discipline (Gordy \& Howells, 2006).

In the wake of 2008 financial crisis and its negative consequences on the economies of developed countries in Europe and United States of America, attention was directed to the institution who is responsible for the formulation of the standards and norms of controlling the banking system, Basel Committee. Basel II standards and norms failed to provide financial protection for financial institutions around the world and protect them against collapse and exposure to losses, where many weaknesses related to high risk investments, risk management operations, assets evaluation, disclosure, transparency, stress tests, liquidity management and capital adequacy emerged (BCBS, 2012). The previous weaknesses in Basel II standards and norms represent the main pillars in forming Basel III standards and norms in 2010. The new set of standards states that banks should 
increase the minimum equity requirements of common shares. In addition, banks will be required to maintain a capital reserve to meet future financial stress periods, so that the ratio of equity rights to common shares is set at $7 \%$, in order to reduce the exposure to future financial crises, and enable for more coverage and protection against different risks that banks might expose to such as credit risk, operational risk and market risk.

\subsection{Literature Review}

There are multiple studies related to the effect of Basel Committee rules and regulatory restrictions and macroeconomic variables on the performance of banks. The findings of these studies represent a base for this study and support it by one way or another. These studies are summarized in table (1).

Table 1. Literature review

\begin{tabular}{|c|c|c|c|}
\hline Author(s) & $\begin{array}{l}\text { Study Period } \\
\text { \& Population }\end{array}$ & Examined Variables & Conclusions \\
\hline $\begin{array}{l}\text { Pasiouras, } \\
\text { Fotios, Sailesh } \\
\text { Tanna, } \\
\text { and } \\
\text { Constantin } \\
\text { Zopounidis } \\
\text { (2009) }\end{array}$ & $\begin{array}{l}2000-2004 \\
74 \text { countries }\end{array}$ & $\begin{array}{l}\text { capital adequacy requirements, official } \\
\text { supervisory power, market discipline } \\
\text { mechanisms, cost and profit efficiency of } \\
\text { banks }\end{array}$ & $\begin{array}{l}\text { The study concluded that banking system regulations } \\
\text { that enhance market discipline and empower the } \\
\text { supervisory power of the monetary authority increase } \\
\text { both cost and profit efficiency of banks. Moreover, } \\
\text { stricter capital requirements improve cost efficiency } \\
\text { but reduce profit efficiency, while restrictions on } \\
\text { bank activities reduce cost efficiency and improve } \\
\text { profit efficiency. }\end{array}$ \\
\hline $\begin{array}{l}\text { Samy Ben } \\
\text { Naceur } \\
\text { and } \\
\text { Magda Kandil } \\
2009\end{array}$ & $\begin{array}{c}\text { 1989-2004 } \\
\text { Egypt }\end{array}$ & $\begin{array}{l}\text { Returns on assets, returns on equity, } \\
\text { earning assets to total assets, overhead to } \\
\text { total assets, required reserve ratio, net } \\
\text { interest revenue over average } \\
\text { interest-bearing assets, net interest income } \\
\text { over average total assets; inflation, real } \\
\text { GDP and potential GDP }\end{array}$ & $\begin{array}{l}\text { The study concluded that new capital regulations } \\
\text { have significantly increased both the cost of financial } \\
\text { intermediation process and the level of liquidity. } \\
\text { In the post regulation period, there were no } \\
\text { significant improve in management efficiency, cost } \\
\text { efficiency did not change significantly, and there was } \\
\text { no significant change in the market power of } \\
\text { commercial banks. }\end{array}$ \\
\hline $\begin{array}{c}\text { Bill Allen, } \\
\text { Ka Kei Chan, } \\
\text { Alistair Milne } \\
\text { and } \\
\text { Steve Thomas } \\
2012\end{array}$ & $\begin{array}{l}\text { 2001-2010 } \\
\text { United } \\
\text { Kingdom }\end{array}$ & $\begin{array}{l}\text { Risk weighted assets, aggregate demand, } \\
\text { aggregate supply, inflation, risk adjusted } \\
\text { capital ratio and liquid assets to total assets } \\
\text { ratio. }\end{array}$ & $\begin{array}{l}\text { As a respond to Basel III adjustments, the cost of } \\
\text { credit to low risk borrowers will be only moderately } \\
\text { affected; however, there will a reduction in the } \\
\text { available credit to high risk activities and the cost of } \\
\text { financing such credit will significantly increase. In } \\
\text { addition, the importance of securitization will } \\
\text { increase as an alternative way of financing the risky } \\
\text { activities and the new liquidity rules could create new } \\
\text { unintended systemic risks. }\end{array}$ \\
\hline $\begin{array}{l}\text { Sami Ben } \\
\text { Naceur } \\
\text { and } \\
\text { Magda Kandil } \\
2013\end{array}$ & $\begin{array}{l}\text { 1989-2004 } \\
\text { Egypt, } \\
\text { Jordan, } \\
\text { Lebanon, } \\
\text { Morocco } \\
\quad \& \\
\text { Tunisia. }\end{array}$ & $\begin{array}{l}\text { Real change in total assets, net loans over } \\
\text { total assets and banks' holdings of } \\
\text { government securities over total assets, } \\
\text { GDP growth rate, interest rate and } \\
\text { inflation rate. }\end{array}$ & $\begin{array}{l}\text { The study concluded that there was significant } \\
\text { increase in credit growth following the } \\
\text { implementation of capital regulations. This means } \\
\text { that at higher capital adequacy ratios, banks managed } \\
\text { to expand credit and asset growth, where credit } \\
\text { growth appears to be driven by demand fluctuations } \\
\text { attributed to real growth, cost of borrowing, and } \\
\text { exchange rate risk. In other words, the effects of } \\
\text { macroeconomic variables appear to be more } \\
\text { dominant in determining credit growth. }\end{array}$ \\
\hline $\begin{array}{c}\text { Osama A. } \\
\text { El-Ansary } \\
\text { and } \\
\text { Hassan M. } \\
\text { Hafez } \\
2015\end{array}$ & $\begin{array}{c}\text { 2004-2013 } \\
\text { Egypt }\end{array}$ & $\begin{array}{l}\text { Capital adequacy; the ratio of earning } \\
\text { assets to total assets, the ratio of securities } \\
\text { to total assets, the ratio of provisions to } \\
\text { total loans, the ratio of loans to deposits, } \\
\text { return on assets, log assets (asset size), the } \\
\text { ratio of net loans to total assets; the ratio } \\
\text { of loans loss reserves to total loans and } \\
\text { return on equity. }\end{array}$ & $\begin{array}{l}\text { The study concluded that determinants of capital } \\
\text { adequacy are not static over time for Egyptian banks. } \\
\text { Till year 2008, assets liquidity and quality of } \\
\text { management were the dominant variables in } \\
\text { determining the variation in capital adequacy. } \\
\text { Starting from } 2009 \text {, factors such as assets quality, size } \\
\text { and profitability arise as important variables in } \\
\text { explaining the variation in capital adequacy. }\end{array}$ \\
\hline
\end{tabular}




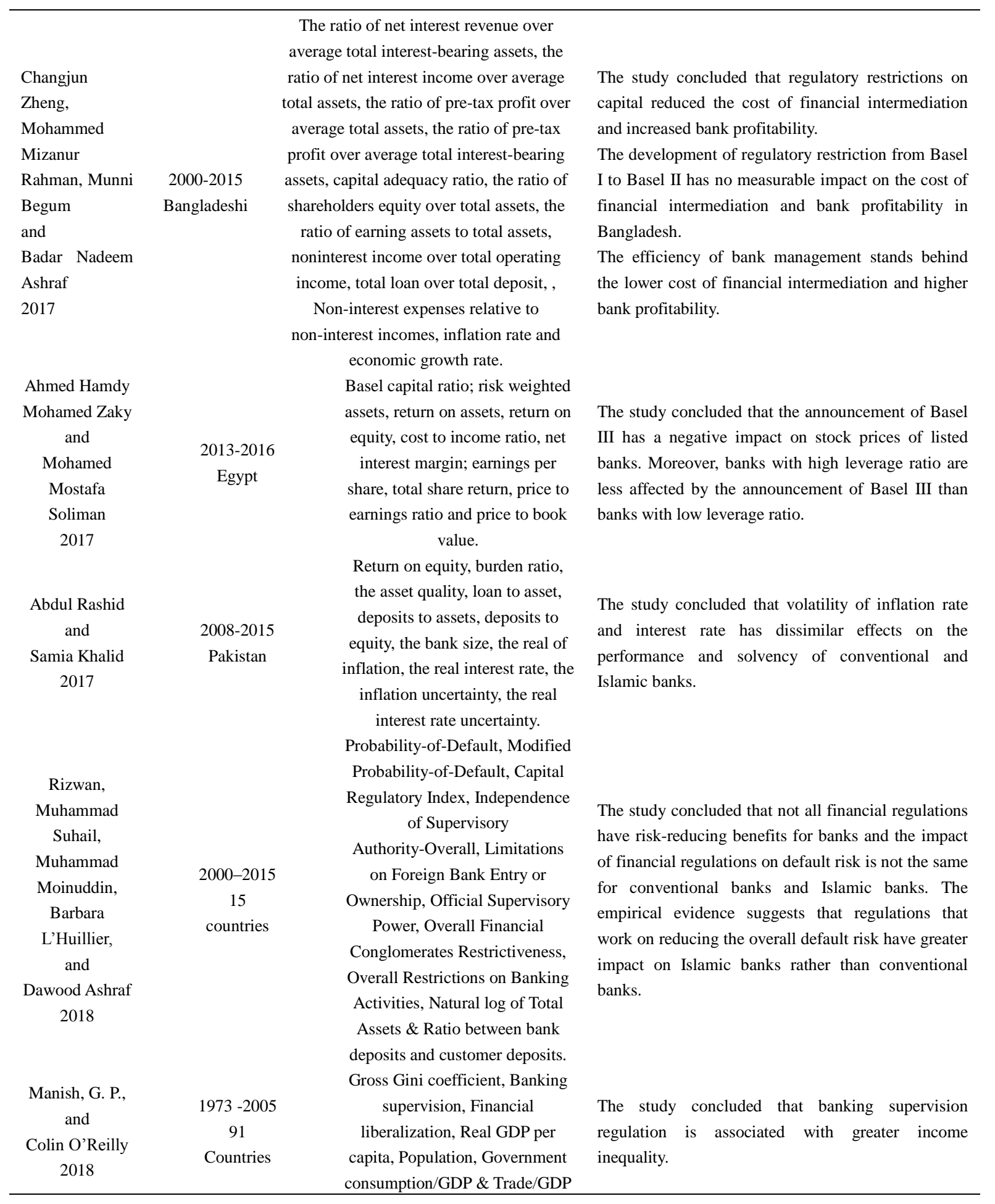

\section{What is new with this study?}

Despite the effect of macroeconomic variables on the performance of banks has been experienced by a number of studies such as Athanasoglou et al. (2008); Naceur and Kandil (2013); Rashid and Khalid (2017); however, these studies did not consider the return on government securities, classified by Basel Committee as low risk assets, as a determinant of bank profitability. Thus, this study will examine the effect of the return on government securities on bank profitability. In addition, this study will examine the direct effect of economic growth on the performance of banks, where Naceur and Kandil (2013) pointed out to just the indirect effect of economic growth on the performance of banks through the effect of economic growth on the size of granted loans. 
This study introduces mixed methodologies in determining the effect of development of banks' regulatory standards and norms on the profitability of banks. These methodologies are based on factor analysis and event study techniques applied on aggregate data of banking sector, financial data of individual bank units and macroeconomic indicators for a relatively longer time series and more comprehensive data of banks listed on Egyptian Exchange relative to other studies such as Zaky and Soliman (2017).

\subsection{Study Problem}

The successive changes in the contemporary business environment and development of international regulatory restrictions on banks are expected to raise number of challenges for Egyptian banks as individual units and as a whole sector.

Regarding individual bank units:

- Maintaining a high level of profitability while complying with Basel III standards will be difficult especially in the light of bad economic conditions experienced by the country, where increasing the cost of capital and the cost of liquidity will negatively affect the profit margins of most bank units (the mean of return on average assets of Egyptian Banks is $0.8429 \%$ and it fluctuated between $0.1 \%$ to $2 \%$ during the period 2003-2016).

- The development of liquidity measurements and standards like Liquid Concentrate Repair (LCR) and Net Stable Funding Ratio (NSFR) will make bank units compete vigorously with each other to attract retail and corporations' deposits, in addition to the increasing tendency of granting loans and facilities with less than one-year maturities to be able to comply with the Net Stable Funding Ratio (NSFR).

- Egyptian banks have to consider number of factors such as: assets liquidity and improving the process of liquidity risk management, assets' size and profitability, and the quality of management were these factors are essential in determining the level of capital adequacy which is a main pillar to cope with different financial crises. In addition, Egyptian banks' plans have to include stress tests and contingency funding plan.

Regarding the banking sector as a whole:

- Preserving a portion of bank capital as a margin to protect against any future pressures may limit the distribution of profits, payment of dividends and repurchasing operations of shares, which negatively affects the fair value of banking sector shares in addition to the negative impact on the market value of shares in the secondary market (till July 2017, only 5 stocks out of 13 banks' common stock listed on Egyptian Exchange managed to exceed their 2008 market values).

- Granting credit will become more stringent and interest rate adjustments will be more dynamic with changes in business environment.

- In order to decrease investment in risky assets, banks are expecting to expand their purchases of government securities, which limit the amount of funding available for the private sector. In other words, the crowding out effect will be worsened.

- If the effect of macroeconomic variables on the size of credit granted by banks is more dominant relative to the capital adequacy variable as stated by Naceur and Kandil (2013); then the study expects to find simultaneous effect of both macroeconomic and capital adequacy variables on the operational performance of banks. In other words, it can be said that regulatory requirements of Basel (I) (II) (III) may have direct and indirect effects on the operational performance of banks under different economic growth rates and other macroeconomic variables, and that the effect of these variables may extend to the performance of banks' stocks and prevent achieving peak market values relative to 2008 market values during the time period from 2003 to 2017.

\subsection{Study Objective}

This study examines the potential effect of the development of regulatory restrictions of Basel's standards and norms on Egyptian banks through dual-level analysis on the profitability of banking sector, profitability of a sample of individual bank units and performance of banks' common stocks in Egyptian Exchange market. The following figure illustrates the study layout. 


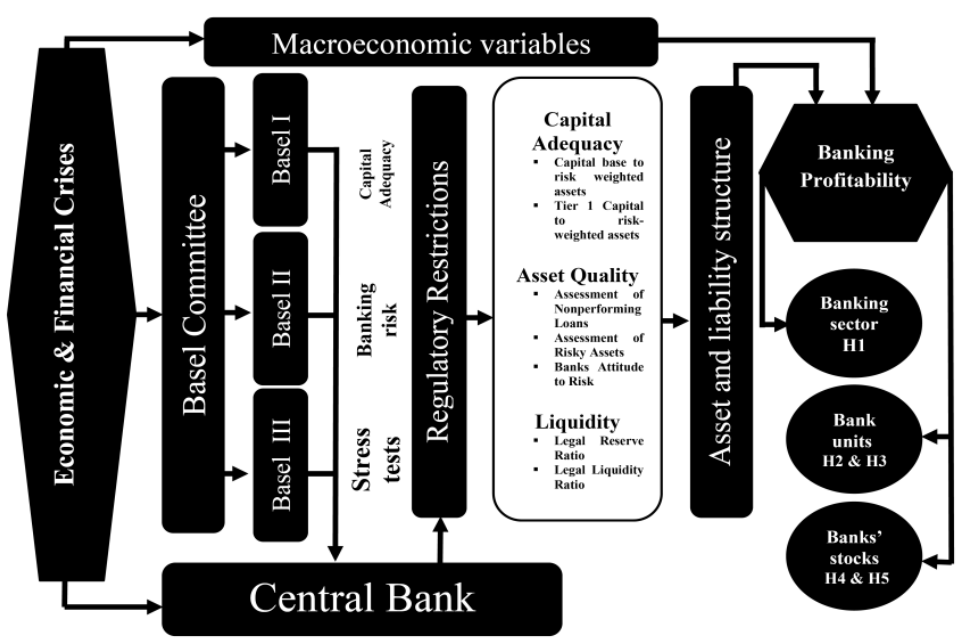

Figure 1. Study layout

Figure 1 shows that Basel Committee emerged as a response to the negative effects of economic and financial crises on the banking sector and designed a number of regulatory restrictions and spread these regulations all over the world through Central Banks to supervise and control the performance of commercial banks and to work as a caution against different risks confront by commercial banks. On one hand, these regulations have had a number of repercussions on banks performance and, on the other hand, the economic and financial crises have their effects on number of macroeconomic variables which in turn affect assets and liabilities structure of commercial banks and eventually affect the performance of commercial banks.

In this context, a number of inquiries have been raised such as:

- What is the effect of both the development of regulatory restrictions and macroeconomic variables on the profitability of banking sector in Egypt?

- What is the effect of both the development of regulatory restrictions and macroeconomic variables on the profitability of individual bank units in Egypt?

- Does the performance of banks' common stocks vary with the development of regulatory restrictions and different macroeconomic variables?

\subsection{Study Hypotheses}

- The development of banks' regulatory restrictions and macroeconomic variables has significant effect on the profitability of banking sector in Egypt.

- The development of banks' regulatory restrictions has a positive effect on interest returns to loan ratio of bank units in Egypt.

- The development of banks' regulatory restrictions has a positive effect on the ratio of net operating income to assets of individual bank units in Egypt.

- The development of banks' regulatory restrictions has significant effect on the returns of Egyptian banks' common stocks.

- The development of banks' regulatory restrictions has significant effect on the total risk characteristics of Egyptian banks' common stocks.

\subsection{Study Methodology}

The study used dual-level analysis on three dimensions for testing the study hypotheses. The first level examines the performance of banking sector through factor analysis technique, which enables for selecting profitability determinants of banking sector with different financial positions indicators, regulatory restrictions and macroeconomic variables $\left(\mathrm{H}_{1}\right)$. The second level examines the performance of individual bank units through event study technique, which enables for experiencing both the profitability of individual bank units $\left(\mathrm{H}_{2}\right)$ and the performance of their common stocks $\left(\mathrm{H}_{3}\right)$ in the light of the development of regulatory restrictions and dynamic economic environment. 


\section{A Glance on the Development of Basel Committee and its Regulatory Restrictions}

\subsection{The Origin and Objectives of Basel Committee}

Basel Committee has been established in 1974 by a decision of Central Bank governors of a group of 10 industrialized countries: Belgium, Canada, France, Germany, Italy, Japan, Luxembourg, Spain, Switzerland, the United Kingdom and the United States under the auspices of the Bank for International Settlements (BIS). The purpose of Basel Committee is to determine the minimum limits on capital adequacy of banks, develop and improve techniques for controlling the operation of banks and to facilitate the diffusion and exchange of information on the procedures and methods of control adopted by different monetary authorities worldwide.

\subsection{Types of Risks Covered by Basel I Standards}

In 1988, Basel Committee determined the minimum capital to be met by banks at $8 \%$ of risk weighted assets plus conditional obligations weighted by their risk weights (Basel, 1988). According to Basel I norms, capital consists of two tranches: Core Capital and Supplementary Capital. Where the core capital is the paid-up capital, reserves and retained earnings, the supplementary one consists of undeclared reserves, assets revaluation reserves, provision for non-specific general risks, subordinated loans and other capital instruments.

In 1995, another tranche has been added to capital represented by two-years loans to cover only market risks. Market risks, as described in the proposed amendment to Basel I, include the followings:

1) Risks related to factors with direct and indirect effect on the returns and value of securities in banks' portfolios.

2) Exchange rate risk.

3) Interest rate risk.

4) Equity risk.

\subsection{Types of Risks Covered by Basel II Standards}

Basel II committee focused on three basic pillars: minimum capital requirements, continuous monitoring of these requirements, and market discipline. Basel II decisions differ from those of Basel I in the form of capital adequacy ratio, where the operational risk is added to the denominator of the fraction of capital adequacy ratio. Basel II did not modify the methods of measuring market risk, but it modified the credit risk measurement methods.

the following points represent the main differences between Basel I and Basel II:

1) Basel I set minimum capital requirements for both credit risk and market risk, while Basel II added operational risk to minimum capital requirements.

2) Basel II classified risks more precisely by adjusting asset categories to include all granted loans.

3) Basel II introduced new ways of measuring credit risk, allowing banks to use the external credit rating of specialized agencies or relying on the internal classification of banks if they have the internal systems capable of doing so.

4) In Basel I, weights of asset credit risk range from $0 \%$ to $100 \%$, whereas in Basel II they range between $0 \%$ and $150 \%$.

5) Basel II standards added two new pillars, regulatory review and market discipline, as complements to the first and only pillar of Basel I, the minimum capital requirements.

\subsection{Types of Risks Covered by Basel III Standards}

The emergence of Basel III standards was a response to the deficiencies of banks' regulations that were noticed during the 2008 global financial crisis. Basel III standards aim at improving the banking system ability to absorb shocks arise from financial and economic crises and pressures. Basel committee further strengthened the liquidity framework by developing liquidity financing standards, and these measures were developed to achieve the following objectives:

1) Improving short-term elasticity of liquidity risk by ensuring that there are sufficient high-liquid assets to ensure stable liquidity risk under one-month of continuous pressure scenario.

2) Improving long-term elasticity of liquidity risk by creating additional incentives for banks to finance their activities using fixed sources of finance on a continuous basis. 


\subsection{Expected Challenges with Basel III}

The norms and accords of Basel III will eventually affect all banks; however, this effect may vary according to the differentiated characteristics of banks. The followings are the main challenges that commercial banks are expected to face with Basel III regulations.

1) The fundamental defects of Basel I and II are not fully addressed by Basel III norms. For instance, the risk weighting system still suffers from the invalid assumption of indifferent portfolios.

2) Banks in different countries are facing differentiated sets of risks which may not all covered by Basel's standards.

3) Basel III has not adequately addressed a number of issues related to prudential risk management such as corporate governance, market transparency and the quality of supervisors; however, these factors contributed to bank failures during financial crises.

4) It may not be prudent to treat all government bonds as non-risky assets considering that their volatility may influence the solvency of banks.

5) Basel committee have tried to incorporate all risk categories such as credit risk, liquidity risk, market risk, operational risks, and foreign exchange risks while calculating the capital adequacy of banks, classifying the asset into various risk categories and designing a proper risk management governance system; however, some risk measurement methodologies, such as Value at Risk (VaR) models, still have limitations where tail risks are still difficult to be predicted, and the systemic risk measurement tools are still in the development phase. In addition, adjusting these risk measurements for capital adequacy will be difficult especially when the economy is experiencing cyclical process of ups and downs.

\section{Data Description and Hypotheses Testing}

\subsection{Data}

The annual data of the study cover the time period 2003-2016 and are used for both sector and individual bank units. The data consist of components of banks' balance sheet as a sector and individual bank units, in addition to data of macroeconomic variables of the Egyptian economy. For individual bank units, the data cover a sample of 13 banks of which 10 are traditional commercial banks and 3 are Islamic banks. Table 2 shows the banks included in the sample of the applied study and the date of listing their shares on the Egyptian Stock Exchange.

Table 2. The Egyptian Banks in the Sample of the Applied Study

\begin{tabular}{lcc}
\hline Listed Securities & REUTERS & LISTING DATE \\
\hline Société Arabe Internationale De Banque (SAIB) & SAIB.CA & $29 / 11 / 1980$ \\
Suez Canal Bank & CANA.CA & $15 / 09 / 1982$ \\
Housing \& Development Bank & HDBK.CA & $13 / 09 / 1983$ \\
Egyptian Gulf Bank & EGBE.CA & $17 / 11 / 1983$ \\
Al Baraka Bank Egypt & SAUD.CA & $25 / 12 / 1984$ \\
National Bank of Kuwait- Egypt- NBK & NBKE.CA & $12 / 09 / 1994$ \\
Commercial International Bank (Egypt) & COMI.CA & $02 / 02 / 1995$ \\
Faisal Islamic Bank of Egypt - In EGP & FAIT.CA & $07 / 06 / 1995$ \\
Union National Bank - Egypt " UNB-E & UNBE.CA & $05 / 11 / 1995$ \\
Export Development Bank of Egypt (EDBE) & EXPA.CA & $14 / 12 / 1995$ \\
Abu Dhabi Islamic Bank- Egypt & ADIB.CA & $19 / 06 / 1996$ \\
Qatar National Bank Alahly & QNBA.CA & $03 / 07 / 1996$ \\
Credit Agricole Egypt & CIEB.CA & $03 / 07 / 1996$ \\
\hline
\end{tabular}

Source: The Egyptian Exchange.

This study excludes the stocks of Banque Du Caire where its stock has been listed on the Egyptian Exchange on 19-02-2017; however, no trade transactions took place on these shares so far and Initial Public Offering (IOP) is expected.

\subsection{Data Description at Sectoral Level}

3.2.1 Overview of the Development of Banking Sector Structure in Egypt

The structure of banking sector in Egypt experienced noticeable changes regarding the number of operating 
banks during the time period 2003-2016, where the number of operating banks decreased from 62 banks in 2003 to 38 banks in 2016 (-38.7\%); however, the number of branches increased by $50 \%$ during the same time period, where the number of branches increased from 2588 branches in 2004 to 3882 branches in 2016, see figures (2) and (3).

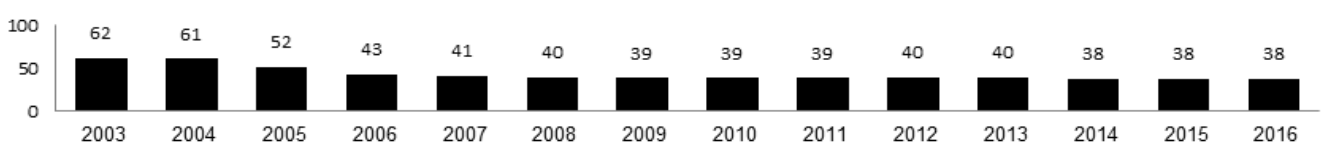

Figure 2. Number of banks operating in Egypt

Source: Central Bank of Egypt; Economic Review; Miscellaneous Issuance from 2008/2009 No.4 to 2016/2017 No.3.
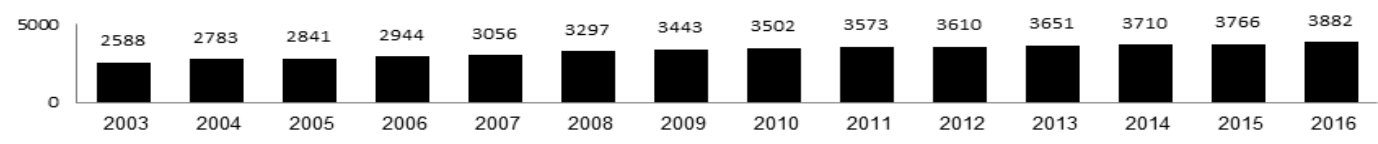

Figure 3. Number of banks' branches in Egypt

Source: Central Bank of Egypt; Economic Review; Issuance from 2008/2009 No.4 to 2016/2017 No.3.

The changes in the number of both operating banks and branches may be explained by the ability of banks to cope with changes in the regulatory restrictions set by Egyptian Central Bank according to recommendations of the Basel committee. The Central Bank of Egypt made a number of efforts to reform and develop the banking sector by executing voluntary or compulsory mergers and acquisitions operations between banks to meet minimum capital requirements.

\subsubsection{A Glance on the Financial Inclusion in Egypt}

The level of financial inclusion in the Middle East and North Africa (MENA) region is one of the lowest worldwide. According to World Bank statistics, in 2014 Egypt suffers from high levels of financial exclusion, where only about $12 \%$ of Egyptians and $14 \%$ of adults are having bank accounts. This may be attributed to a number of factors. Relative high size of the informal sector in Egypt, high unemployment and poverty rates come on the top of these factors. In addition, Egypt is considered a cash-based economy, where cash transactions dominate most activities in the economy. Table 3 illustrates the efforts taken by Egypt regarding the issue of Financial Inclusion.

Table 3. Egyptian microscope on financial inclusion, 2016.

Score 100

\begin{tabular}{lc}
\hline Government Support for Financial Inclusion & 22 \\
Regulatory and Supervisory Capacity for Financial Inclusion & 25 \\
Prudential Regulation & 38 \\
Regulation and Supervision of Credit Portfolios & 56 \\
Regulation and Supervision of Deposit-Taking Activities & 38 \\
Regulation of Insurance for Low-Income Populations & 8 \\
Regulation and Supervision of Branches and Agents & 72 \\
Requirements for Non-Regulated Lenders & 50 \\
Regulation of Electronic Payments & 50 \\
Credit Reporting Systems & 42 \\
Market Conduct Rules & 19 \\
Grievance Redress and Operation of Dispute Resolution Mechanisms & 25 \\
\hline
\end{tabular}

Source: Global Microscope on Financial Inclusion Data, 2016.

It can be said that low level of financial inclusion is one of the main challenges to the prosperity of the banking sector in Egypt and may represent another reason for the modest size and role of banking sector in the Egyptian economy.

\subsubsection{Data of Banking Sector's Balance Sheet}

Figure 4 illustrates that the most important components of banking sector's balance sheet (total assets, deposits, 
loans, securities and total equity) have followed an upward sloping trend from 2003 to 2016. Regarding the type of investments in banks' portfolios, the study found that the relative weight of total loans has followed a decreasing trend while the relative weight of securities, especially government securities, has followed an upward sloping trend. The changes in the relative weights of loans and securities can be explained in two ways: first, the public budget deficit has been exaggerated with a tendency by the Egyptian government to finance this deficit through internal borrowing; second, there is a tendency of banks to invest in a relatively safer investment.

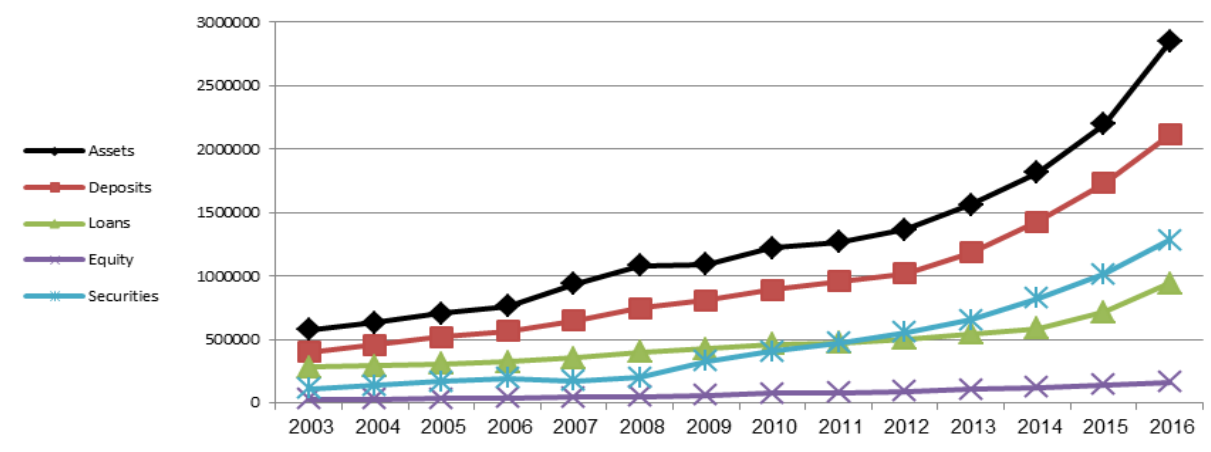

Figure 4. Egyptian banking activities (at end of June)

Source: Central Bank of Egypt; Economic Review \& Annual Reports; Miscellaneous Issuance.

\subsubsection{Indicators of the Performance of Egyptian Banking Sector}

The performance of banking sector has been experienced by a number of empirical researches through several methodologies and measurements. In this study we used a number of financial ratios to examine the performance of Egyptian banks and determine the effect of the regulatory restrictions imposed by the Egyptian Central Bank on the profitability and operating standards of commercial banks. Return on assets, return on equity and capital adequacy ratio are considered important financial indicators regarding the performance of banking sector. The behavior of these indicators, regarding the Egyptian banking sector, are illustrated in figures 5, 6 and 7.

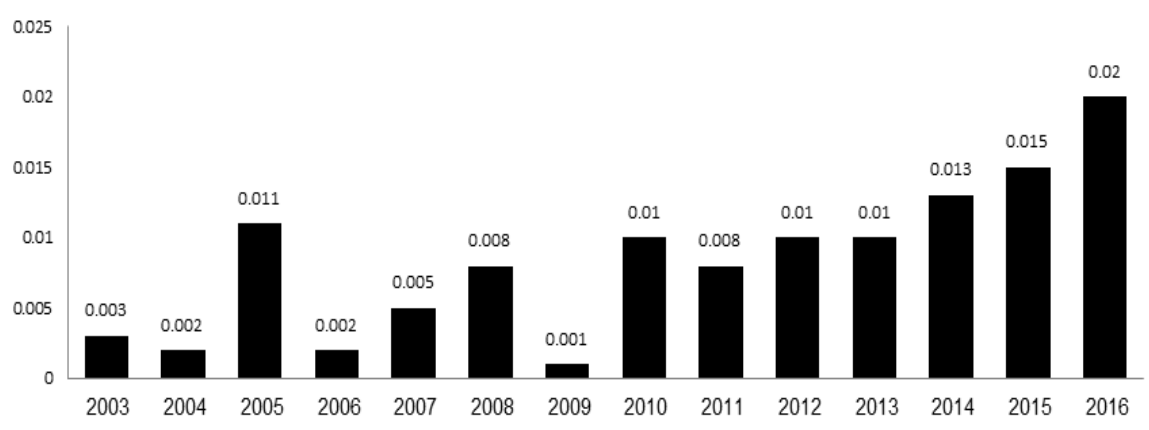

Figure 5. Return on average assets of Egyptian banking sector

Source: Central Bank of Egypt; Economic Review \& Annual Reports; Miscellaneous Issuance.

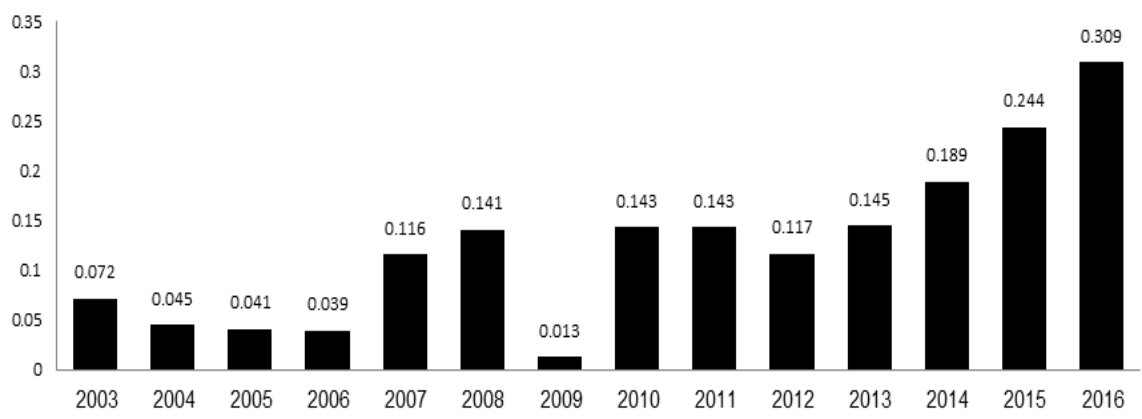

Figure 6. Return on average equity of Egyptian banking sector

Source: Central Bank of Egypt; Economic Review \& Annual Reports; Miscellaneous Issuance. 


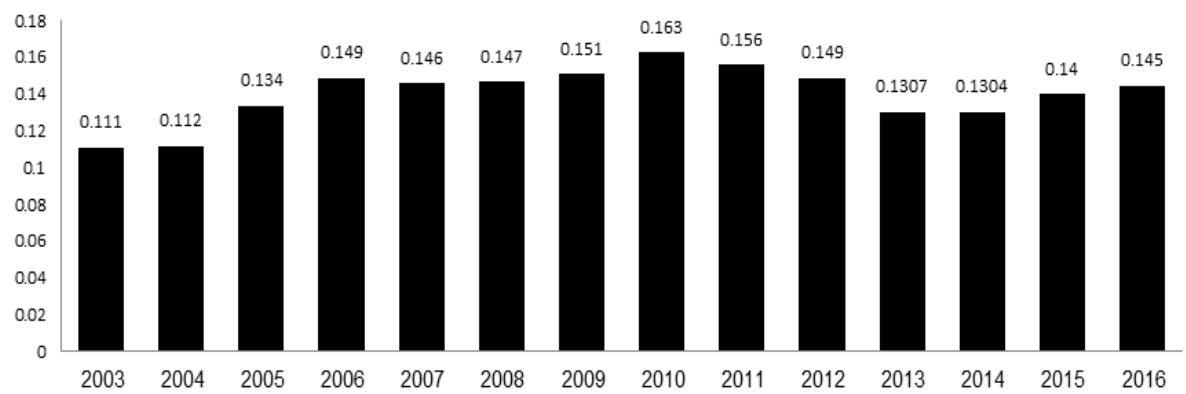

Figure 7. Capital adequacy ratio of Egyptian banking sector

Source: Central Bank of Egypt; Economic Review \& Annual Reports; Miscellaneous Issuance.

The previous figures show that there is a tendency to maintain a minimum rate of capital adequacy at $10 \%$ as planned in the first phase of reforming the banking sector by the Egyptian Central Bank and this extended to the second phase; then, the banking sector exposed to the global financial crisis in 2008. The repercussions of the financial crisis on the banking sector appeared in a relatively low rate of return on assets and equity in 2009. In 2012, the gradual implementation of Basel III norms started to take place and because changing the technique of calculating the capital adequacy ratio was on the top of these norms, requiring formation of provision to support capital, the rates of capital adequacy and return on equity responded negatively; however, these rates and indicators started to improve from year 2014 after adjustment to the new set of regulations.

\subsection{Data Description at Individual Bank Units and their Common Stock Performance}

\subsubsection{The Performance of Common Stocks of Individual Bank Units}

The participation of bank units in Egyptian Exchange is a relatively modest one, where just 13 units out of 40 bank units have listed stocks in the stock market. Table 4 represents the performance of common stocks of bank units in the study sample.

Table 4. The performance of common stocks of bank units in the Egyptian stock market

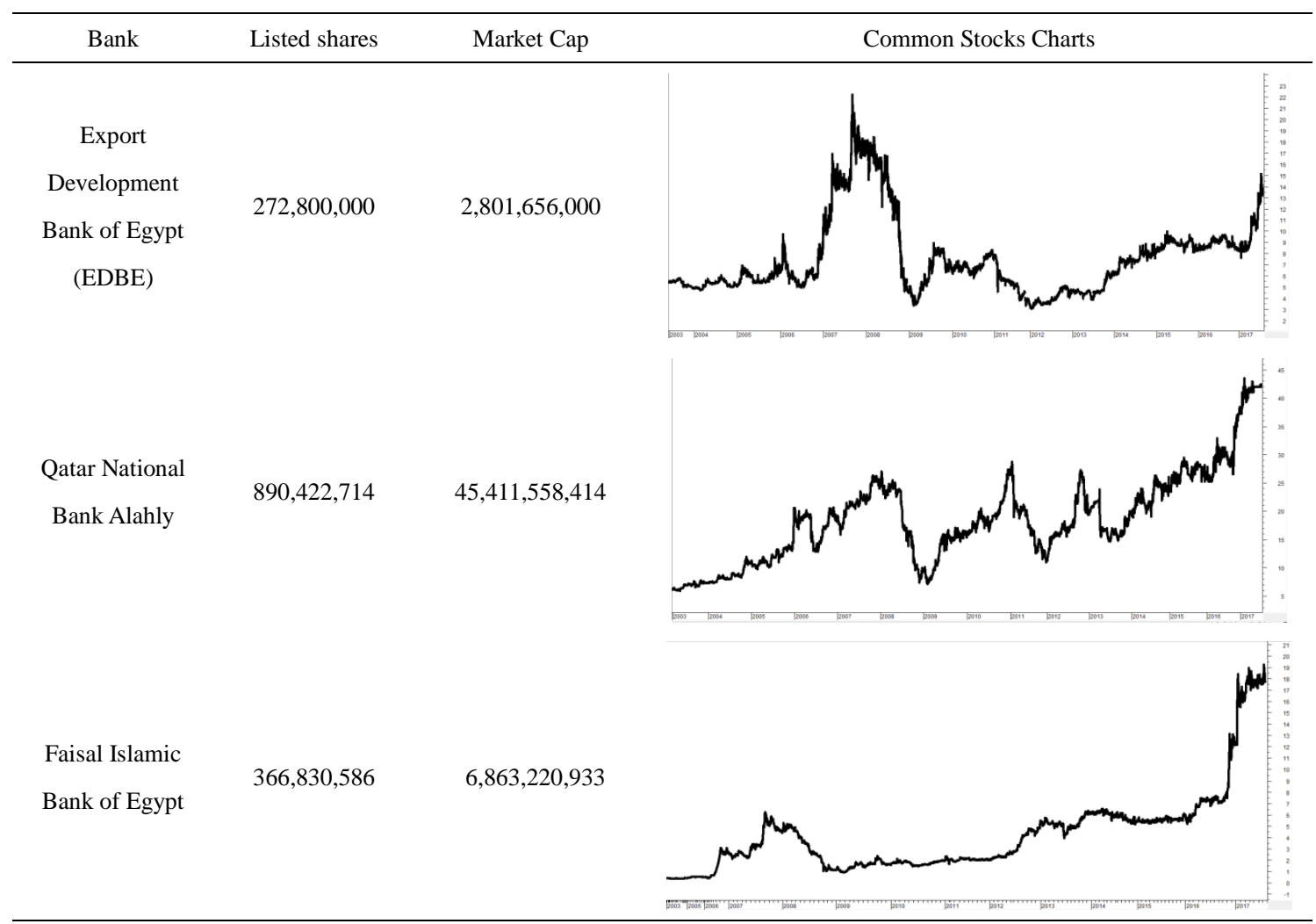




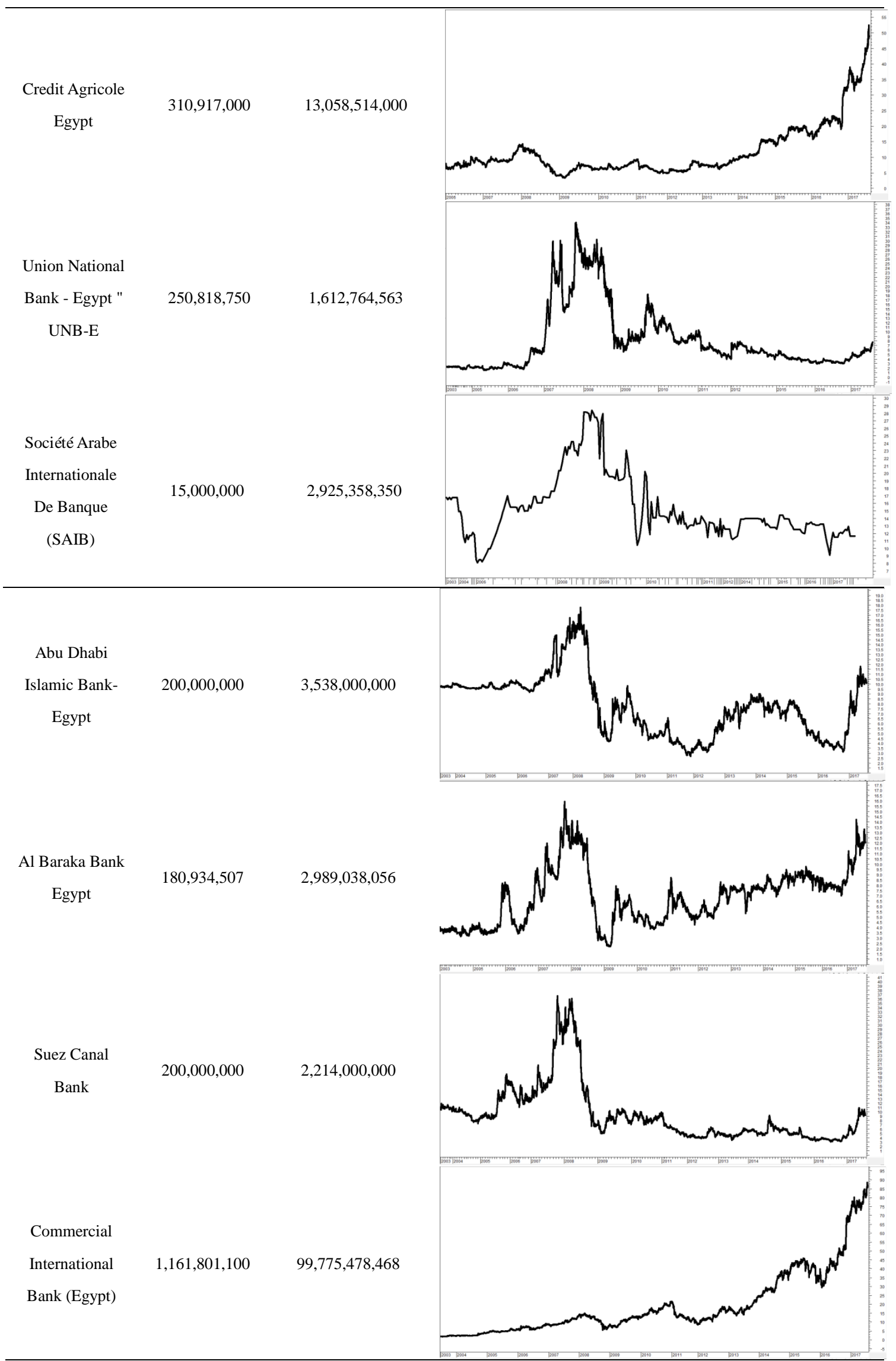




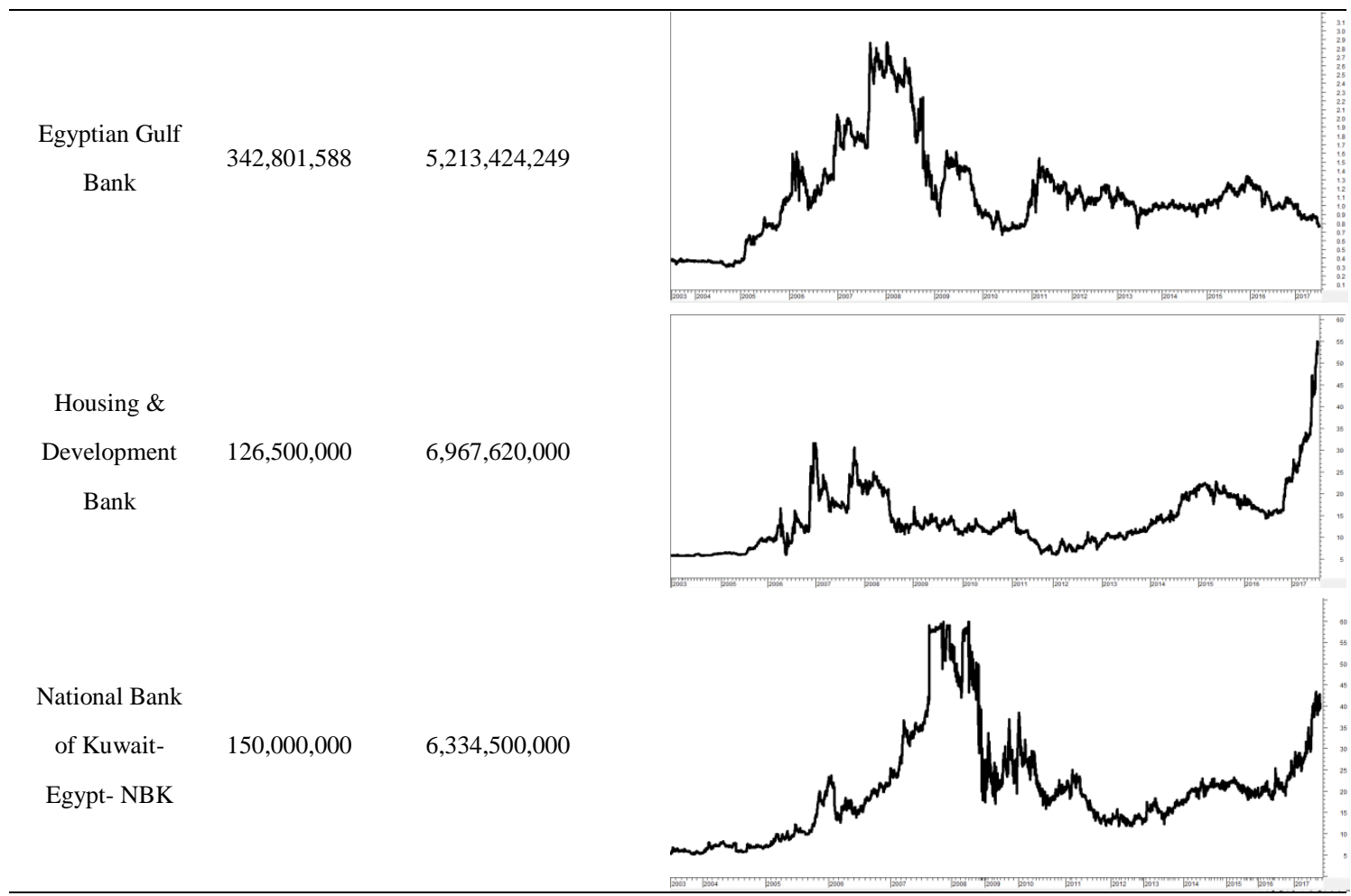

Source: Prepared by the authors based on data extracted from The Egyptian Exchange.

The previous figures show that till year 2017, the common stocks of only 5 bank units managed to exceed their peak levels achieved in year 2008. This may explain the dissimilar effect of 2008 financial crisis and the associated financial regulations on different bank units.

In order to help investors in making proper and informed investment decisions, EGX launched, for the first time, the Banks index in 2007 with a base value of 1000 points. The Banks index is a free-float market capitalization weighted index. Figure 8 shows the Banks index performance.

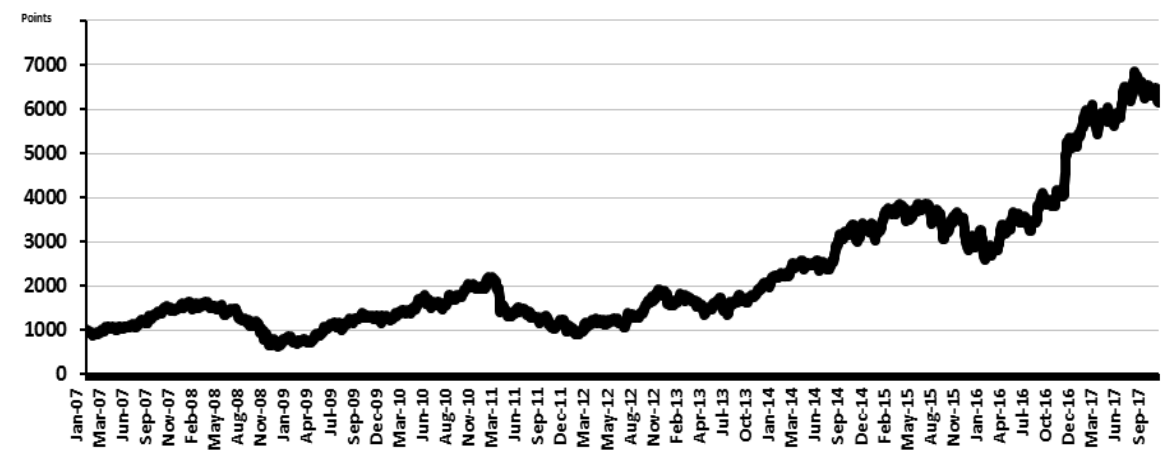

Figure 8. The banks index performance

Source: Authors calculations based on data extracted from the Egyptian Exchange.

From January 2007 to May 2018 the returns on common stocks of bank units, according to the sector index, was $583.6 \%$, however, this return attributed mainly to the contribution of only 5 bank units: Commercial International Bank-Egypt, Qatar National Bank Alahly, Credit Agricole-Egypt, Housing \& Development Bank and Faisal Islamic Bank of Egypt.

\subsubsection{Performance Indicators of Egyptian Bank Units}

The development of Basel norms and standards have had different effect on the return and performance of bank units. The differentiated impact of the development of Basel norms and standards illustrated by figures 9 and 10 . 
Figure 9 shows average interest returns to loans with different regulatory restrictions according to Basel I and Basel II standards.

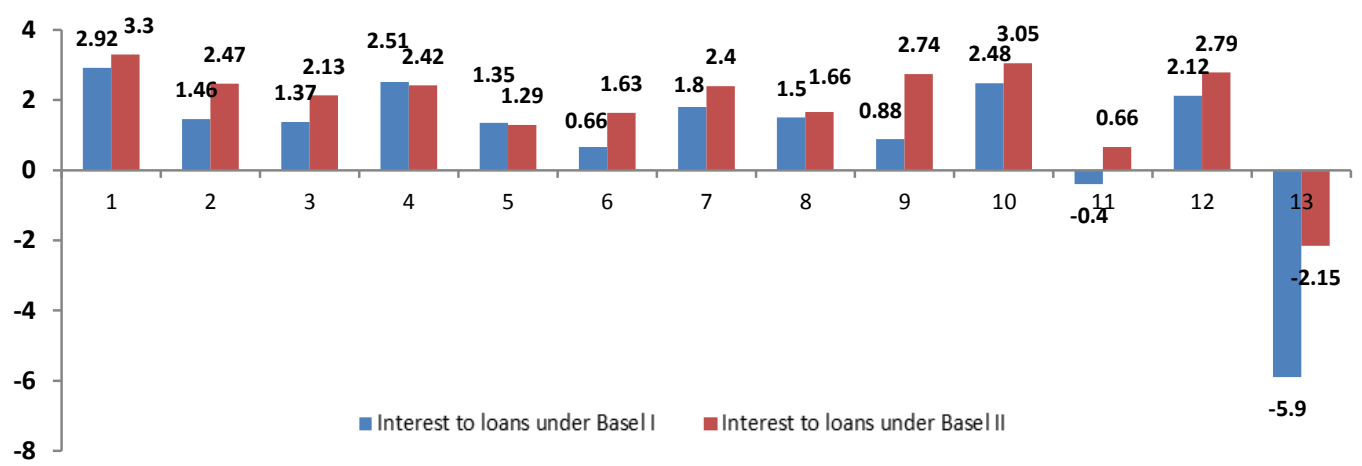

Figure 9. Average interest returns to loans as an index to bank units' profitability

Source: Authors calculations based on data extracted from financial reports of banking units.

Figure 10 shows average net operating income to assets with different regulatory restrictions according to Basel I and Basel II standards.

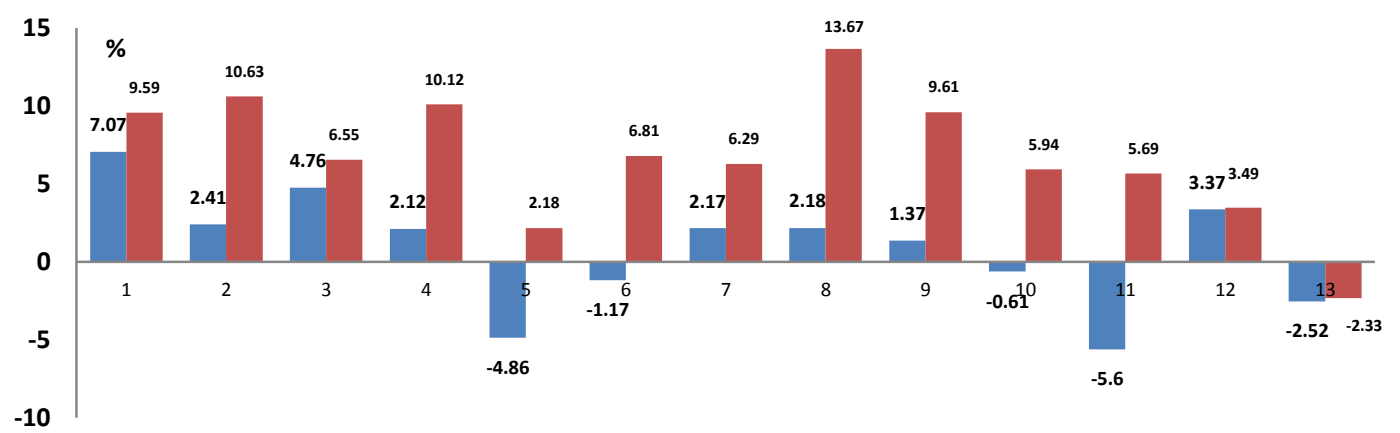

Net operating income to assets under Basel I Net operating income to assets under Basel II

Figure 10. Average net operating income to assets as an index of banks performance

Source: Authors calculations based on data extracted from financial reports of banking units.

The differentiated effect of regulatory restrictions on the performance of bank units may lead us to conclude that the characteristics of different bank units, such as bank size, assets quality, management efficiency, effectiveness of bank governance, play a crucial role in determining the impact of development of Basel norms and standards on the profitability of these units. This agrees with (Pasiouras \& Kosmidou, 2007; Zaky \&Soliman, 2017).

Table 5 shows the development of profitability indicators of bank units, interest returns to loan and net operating income to assets, with different regulatory restrictions according to Basel I and Basel II standards.

Table 5. Development of profitability indicators with different regulatory restrictions

\begin{tabular}{ccccccccc}
\hline $\begin{array}{c}\text { indicators of Egyptian } \\
\text { Banking units Performance }\end{array}$ & $\begin{array}{c}\text { Minimum } \\
\text { Statistic }\end{array}$ & $\begin{array}{c}\text { Maximum } \\
\text { Statistic }\end{array}$ & $\begin{array}{c}\text { Mean } \\
\text { Statistic }\end{array}$ & $\begin{array}{c}\text { Std. Deviation } \\
\text { Statistic }\end{array}$ & $\begin{array}{c}\text { Skewers } \\
\text { Statistic }\end{array}$ & $\begin{array}{c}\text { Std. } \\
\text { Error }\end{array}$ & $\begin{array}{c}\text { Kurtosis } \\
\text { Statistic }\end{array}$ & $\begin{array}{c}\text { Std. } \\
\text { Error }\end{array}$ \\
\hline $\begin{array}{c}\text { Interest Returns to loans with } \\
\text { Basel I }\end{array}$ & 8.26 & 20.67 & 13.6069 & 3.285332009 & 0.735 & 0.616 & 0.8197 & 1.191 \\
$\begin{array}{c}\text { Interest Returns to loans with } \\
\text { Basel II }\end{array}$ & 13.64 & 54.49 & 21.12 & 10.82564702 & 2.838 & 0.616 & 8.661 & 1.191 \\
$\begin{array}{c}\text { Net operating income to } \\
\text { assets with Basel I }\end{array}$ & -5.9 & 2.92 & 0.98077 & 2.24476228 & -2.715 & 0.616 & 8.41101 & 1.191 \\
$\begin{array}{c}\text { Net operating income to } \\
\text { assets with Basel II }\end{array}$ & -2.15 & 3.3 & 1.87615 & 1.417559749 & -2.104 & 0.616 & 5.3817 & 1.191 \\
\hline
\end{tabular}

Source: Statistical Package for the Social Sciences output. 
Table 5 illustrates that the ratio of average interest returns to loan increased from $13.6 \%$ with Basel I regulations to $21.1 \%$ with Basel II regulations; on contrary, the average net operating income to asset ratio decreased from $1.88 \%$ with Basel I regulations to $0.98 \%$ with Basel II regulations. This indicates an improvement in the process of credit management of bank units due to the new set of regulatory restrictions of Basel II on the expense of net operating income as a result of increasing the operational expenses of internal auditing and risk management process, this conclusion agrees with (Allen et al., 2009), (Petria et al., 2015) and (Ozili, 2017), in addition to the tendency of bank units to direct their funds to more liquid and low risk assets such as government securities (see figure 3).

\subsection{The Response of Egyptian Banking System to Different Sets of Regulatory Restrictions}

Factor analysis technique will be used to examine the effect of different regulatory restrictions on the Egyptian banking system. This technique is based on selecting and classifying just a few groups of variables that could have a noticeable effect on the dependent variable. In this study, a multiple number of variables that may affect the profitability of banking sector are used and the factor analysis technique classified these variables into just four groups or factors. Each factor captures a certain amount of the overall variance in the observed variables, and the factors are always listed in order of how much variation they explain; the relationship of each variable to the underlying factor is expressed by the so-called factor loading.

Table 6 shows the relationship of each variable to the underlying factor and it is expressed by the factor loading of performance indicators of Egyptian banking sector and a number of macroeconomic variables. The results indicate four groups of factors as shown in Table 6.

Table 6. Rotated component matrix

\begin{tabular}{ccccc}
\hline \multicolumn{3}{c}{ Component } & & \\
\hline Variable & Sign & F1 & F2 & F3 \\
\hline Economic Growth Rate & X1 & -0.65942 & & 0.578644 \\
Exchange Rate & X2 & 0.584976 & 0.520674 & 0.551637 \\
T-Bill Returns & X3 & 0.668062 & 0.445507 & \\
Inflation Rate & X4 & & & 0.774281 \\
Stock Market Return & X5 & & 0.757005 & \\
Weight of Foreign Currency Deposits & X6 & 0.589124 & 0.42411 & 0.525843 \\
Capital adequacy rate & X7 & & -0.81045 & \\
Net Interest Margin & X8 & 0.959466 & & \\
Liquidity Ratio of Local Currency & X9 & 0.948902 & & \\
Liquidity Ratio of Foreign Currencies & X10 & 0.427792 & 0.518212 & \\
Securities to Assets & X11 & 0.981088 & & \\
Deposits to Assets & X12 & 0.793945 & & \\
Loans to Deposits & X13 & -0.9091 & & -0.46274 \\
Equity to Assets & X14 & 0.832174 & & \\
Securities to Deposits & X15 & 0.983113 & & \\
Balances of Treasury (LOG) & X16 & 0.973629 & & \\
Gross Domestic Debt (LOG) & X17 & 0.978999 & & \\
Treasury bills to GDD & X18 & 0.866655 & & \\
Total Public Budget Deficit Growth Rate & X19 & -0.4501 & 0.617194 & \\
Total Deficit to GDP & X20 & 0.703171 & 0.586739 & \\
Return on Average Assets & Y1 & 0.803565 & & \\
\hline
\end{tabular}

Extraction Method: Principal Component Analysis.

Rotation Method: Varimax with Kaiser Normalization.

Source: Statistical Package for the Social Sciences output.

In the previous Table 6, the study found common variables between the four groups. Accordingly, variables with the lowest coefficient of loading are deleted from the other factors. 
Table 7. Comparative rotated component matrix

\begin{tabular}{|c|c|c|c|c|c|}
\hline \multicolumn{6}{|c|}{ Component } \\
\hline Variable & Sign & $\mathrm{F} 1$ & F2 & F3 & $\mathrm{F} 4$ \\
\hline Economic Growth Rate & $\mathrm{X} 1$ & $\sqrt{ }$ & & & \\
\hline Exchange Rate & $\mathrm{X} 2$ & $\sqrt{ }$ & & & \\
\hline T-Bill Return & $\mathrm{X} 3$ & $\sqrt{ }$ & & & \\
\hline Inflation Rate & $\mathrm{X} 4$ & & & $\sqrt{ }$ & \\
\hline Stock Market Return & $\mathrm{X} 5$ & & $\sqrt{ }$ & & \\
\hline Weight of Foreign Currency Deposits & $\mathrm{X} 6$ & $\sqrt{ }$ & & & \\
\hline Capital adequacy rate & $\mathrm{X} 7$ & & $\sqrt{ }$ & & \\
\hline Net Interest Margin & $\mathrm{X} 8$ & $\sqrt{ }$ & & & \\
\hline Liquidity Ratio of Local Currency & $\mathrm{X} 9$ & $\sqrt{ }$ & & & \\
\hline Liquidity Ratio of Foreign Currencies & $\mathrm{X} 10$ & & & & $\sqrt{ }$ \\
\hline Securities to Assets & $\mathrm{X} 11$ & $\sqrt{ }$ & & & \\
\hline Deposits to Assets & $\mathrm{X} 12$ & $\sqrt{ }$ & & & \\
\hline Loans to Deposits & $\mathrm{X} 13$ & $\sqrt{ }$ & & & \\
\hline Equity to Assets & $\mathrm{X} 14$ & $\sqrt{ }$ & & & \\
\hline Securities to Deposits & $\mathrm{X} 15$ & $\sqrt{ }$ & & & \\
\hline Balances of Treasury Bills (LOG) & $\mathrm{X} 16$ & $\sqrt{ }$ & & & \\
\hline Gross Domestic Debt (LOG) & $\mathrm{X} 17$ & $\sqrt{ }$ & & & \\
\hline Treasury bills to GDD & $\mathrm{X} 18$ & $\sqrt{ }$ & & & \\
\hline Total Public Budget Deficit Growth Rate & X19 & & $\sqrt{ }$ & & \\
\hline Total Deficit to GDP & $\mathrm{X} 20$ & $\sqrt{ }$ & & & \\
\hline Return on Average Assets & $\mathrm{Y} 1$ & $\sqrt{ }$ & & & \\
\hline
\end{tabular}

Source: Prepared by authors based on table 8 data.

Table 7 shows that there are four factors affecting the profitability of banks. The first factor includes a number of variables with relatively high weight effect on the profitability of banks: economic growth rate, exchange rate, T-Bills return, relative weight of foreign currency deposits, net interest margin, liquidity ratio of local currency, securities to assets, deposits to assets, loans to deposits, equity to assets, securities to deposits, balances of treasury bills, gross domestic debt (GDD) and treasury bills to GDD. This factor is nominated in the study as "Assets and liabilities structure of banking Sector and macroeconomic status". The second factor includes three variables: stock market return, capital adequacy ratio and public budget deficit growth rate. This factor is nominated in the study as "Financial Markets Performance and Financial Stability". The third factor includes just one variable: Inflation Rate. Finally, the fourth factor includes just one variable: Liquidity Ratio of Foreign Currencies" and nominated as "Foreign Currencies".

Table 8 shows OLS estimates of return on average assets and return on average equity according to Vector Autoregressive (VAR) models with lag order 1.

Table 8. OLS estimates for banking profitability

\begin{tabular}{|c|c|c|c|c|c|c|c|c|c|}
\hline \multicolumn{10}{|c|}{ VAR system, lag order 1} \\
\hline \multicolumn{10}{|c|}{ OLS estimates, observations 2004-2016 $(\mathrm{T}=13)$} \\
\hline \multicolumn{10}{|c|}{ Log-likelihood $=90.068246$} \\
\hline \multicolumn{10}{|c|}{ Determinant of covariance matrix $=3.2899045 \mathrm{e}-009$} \\
\hline \multicolumn{10}{|c|}{$\mathrm{AIC}=-11.7028$} \\
\hline \multicolumn{10}{|c|}{$\mathrm{BIC}=-11.0944$} \\
\hline \multicolumn{10}{|c|}{$\mathrm{HQC}=-11.8279$} \\
\hline \multicolumn{10}{|c|}{ Portmanteau test: $\mathrm{LB}(3)=17.7936, \mathrm{df}=8[0.0228]$} \\
\hline \multicolumn{5}{|c|}{ Equation 1: Y2 } & \multicolumn{5}{|c|}{ Equation 2: Y1 } \\
\hline \multicolumn{5}{|c|}{ Heteroskedasticity-robust standard errors, variant $\mathrm{HC} 1$} & \multicolumn{5}{|c|}{ Heteroskedasticity-robust standard errors, variant $\mathrm{HC} 1$} \\
\hline & coefficient & std. error & t-ratio & p-value & & coefficient & std. error & t-ratio & p-value \\
\hline const & 0.0781308 & 0.166951 & 0.4680 & 0.6563 & const & 0.0157606 & 0.0108120 & 1.458 & 0.1952 \\
\hline Y2_1 & -0.512089 & 0.372073 & -1.376 & 0.2179 & Y2_1 & -0.0212133 & 0.0233709 & -0.9077 & 0.3990 \\
\hline Y1_1 & 0.674372 & 3.40315 & 0.1982 & 0.8495 & Y1_1 & -0.357430 & 0.284877 & -1.255 & 0.2563 \\
\hline FAC1_1 & 0.0622985 & 0.0196415 & 3.172 & $0.0193 * *$ & FAC1_1 & 0.00434038 & 0.00101377 & 4.281 & $0.0052 * * *$ \\
\hline FAC2_1 & 0.0709884 & 0.0140026 & 5.070 & $0.0023 * * *$ & FAC2_1 & 0.00573902 & 0.00104178 & 5.509 & $0.0015^{* * *}$ \\
\hline X10 & -0.0376073 & 0.359916 & -0.1045 & 0.9202 & $\mathrm{X} 10$ & -0.00908659 & 0.0184736 & -0.4919 & 0.6403 \\
\hline $\mathrm{X} 4$ & 1.13756 & 0.338094 & 3.365 & $0.0151 * *$ & $\mathrm{X} 4$ & 0.0235372 & 0.0432453 & 0.5443 & 0.6059 \\
\hline
\end{tabular}




\begin{tabular}{|c|c|c|c|c|c|c|c|}
\hline Mean dependent var & 0.129615 & S.D. dependent var & 0.084991 & Mean dependent var & 0.008846 & S.D. dependent var & 0.005475 \\
\hline Sum squared resid & 0.014160 & S.E. of regression & 0.048579 & Sum squared resid & 0.000066 & S.E. of regression & 0.003312 \\
\hline R-squared & 0.836645 & Adjusted R-squared & 0.673290 & R-squared & 0.817064 & Adjusted R-squared & 0.634128 \\
\hline$F(6,6)$ & 20.04136 & P-value(F) & 0.000998 & $F(6,6)$ & 68.55396 & P-value(F) & 0.000029 \\
\hline rho & -0.017231 & Durbin-Watson & 1.781464 & rho & -0.413931 & Durbin-Watson & 2.351032 \\
\hline \multicolumn{4}{|c|}{ F-tests of zero restrictions: } & \multicolumn{3}{|c|}{ F-tests of zero restrictions: } & \\
\hline All lags of Y2 & \multicolumn{2}{|c|}{$\mathrm{F}(1,6)=1.8942[0.2179]$} & & All lags of Y2 & $\mathrm{F}(1,6)=$ & $0.82388[0.3990]$ & \\
\hline All lags of Y1 & \multicolumn{2}{|c|}{$F(1,6)=0.039268[0.8495$} & & All lags of Y1 & $\mathrm{F}(1,6)=$ & $1.5742[0.2563]$ & \\
\hline
\end{tabular}

Source: Gnu Regression, Econometrics and Time-series Library output.

Factor analysis revealed that there are four factors with significant effect on banks' profitability through their effects on return on assets and return on equity. The two independent indicators of banks' profitability have been examined by two models. Where $Y_{2}$ is a measure of return on average equity of banking sector, $Y_{1}$ is a measure of return on average assets of banking sector, $\mathrm{F}_{1}$ is a measure of "Assets and liabilities structure of banking sector and macroeconomic status", $\mathrm{F}_{2}$ is a measure of "Financial Markets Performance and Financial Stability", $\mathrm{X}_{4}$ is a measure of Inflation and $\mathrm{X}_{10}$ is a measure of Liquidity Ratio of Foreign Currencies.

The following regression model is used to examine factors that affect the return on average equity of banking Sector:

$$
Y_{2, t}=0.0781308-0.0212 Y_{2, t-1}+0.674372 Y_{1, t-1}+0.00434 F_{1}+0.0709884 F_{2}+1.13756 X_{4}-0.0376 X_{10}
$$

The following regression model is used to examine factors that affect the return on average assets of banking Sector:

$$
Y_{l, t}=0.0157606-0.021 Y_{2, t}-1-0.35743 Y_{1, t-1}+0.00434 F_{1}+0.005739 F_{2}+0.0235372 X_{4}-0.00908659 X_{10}
$$

Despite the two regression models are valid at $1 \%$ significant level; however, the validity of explanatory variables varies between the two modules as follows:

- Inflation rate variable, as a determinant of banks' profitability, is valid in one model and invalid in the other one. This may be attributed to price distortion of some commodities with high weights in the market basket that used in the calculation of Consumer Price Index, where the prices of bread and gasoline are subject to mandatory prices set by the Egyptian government. This decreases the quality of measuring domestic price inflation.

- Formal Egyptian exchange rate variable, as a determinant of banks' profitability, is insignificant in both models. This may be attributed to the imposition of price ceilings on exchanging the US dollar for Egyptian pound, the case which ended by the flotation of the Egyptian pound by the end of 2016 and depreciation of Egyptian pound against US dollar by more than $100 \%$.

In general, we may conclude that the development of banks' regulatory restrictions and macroeconomic variables has significant effect on the profitability of banking sector in Egypt

\subsubsection{Examining the Effect of Different Regulatory Restrictions on Interest Returns to Loans}

This hypothesis examines the effect of development of regulatory restrictions on interest returns to loans in Egyptian bank units. The study used Wilcoxon Signed Ranks test to examine this hypothesis as an event study.

Table 9. Wilcoxon signed ranks output for interest returns to loans with the developments of regulatory restrictions

\begin{tabular}{cc}
\hline & Test Statistics \\
\hline Z & Interest to loans with Basel I - Interest to loans with Basel II \\
Asymp. Sig. (2-tailed) & -3.10991168 \\
$\mathrm{a}$ & 0.001871433 \\
$\mathrm{~b}$ & Based on negative ranks. \\
\hline
\end{tabular}

a. Based on negative ranks; b. Wilcoxon Signed Ranks Test.

Source: Statistical Package for the Social Sciences output.

The previous statistical results show that there is a general tendency to change the ratio of interest returns to loans, and it is significant at 0.01 level. In other words, it can be said that the development of regulatory restrictions has a significant effect on interest returns to loans ratio in the Egyptian bank units, where the ratio of 
interest returns to loans tends to increase with the development of regulatory restrictions.

\subsubsection{Examining the Effect of Different Regulatory Restrictions on Net Operating Income to Assets}

This hypothesis examines the effect of development of regulatory restrictions on net operating income to assets in Egyptian bank units. The study used Wilcoxon Signed Ranks test to examine this hypothesis as an event study.

Table 10. Wilcoxon signed ranks output for net operating income to assets with the developments of regulatory restrictions

\begin{tabular}{cc}
\hline & Test Statistics \\
\hline Z & Net operating income to assets with Basel II - Net operating income to assets with Basel I \\
Asymp. Sig. (2-tailed) & -2.970140457 \\
a & 0.002976636 \\
b & Based on positive ranks. \\
\hline
\end{tabular}

a. Based on positive ranks; b. Wilcoxon Signed Ranks Test.

Source: Statistical Package for the Social Sciences output.

The previous statistical results show that there is a general tendency to change the ratio of net operating income to assets, and it is significant at 0.01 level. In other words, it can be said that in the light of the development of regulatory restrictions the ratio of net operating income to assets of Egyptian bank units tends to increase. Thus, the development of regulatory restrictions has a significant positive effect on the net operating income to assets of Egyptian bank units.

3.4.3 Examining the Effect of Different Regulatory Restrictions on the Returns of Egyptian Banks' Common Stocks

This hypothesis examines the effect of development of regulatory restrictions on the returns of Egyptian banks' common stocks. The study used one-way ANOVA Test to examine this hypothesis.

Table 11. One-way ANOVA output for the returns of banks' common stocks with the developments of regulatory restrictions

\begin{tabular}{cccccc}
\hline & Sum of Squares & df & Mean Square & F & Sig. \\
\hline Between Groups & 14.38337 & 1 & 14.38337 & 3.959446 & 0.046751 \\
Within Groups & 6978.363 & 1921 & 3.632672 & & \\
Total & 6992.746 & 1922 & & & \\
\hline
\end{tabular}

Source: Statistical Package for the Social Sciences output.

The previous statistical results show that there is a general tendency to change the returns of banks' common stocks, and it is significant at 0.05 level. In other words, it can be said that in the light of the development of regulatory restrictions the returns of Egyptian banks' common stocks increased; so that the development of regulatory restrictions has a significant positive effect on the improvement of the returns of Egyptian banks' common stocks.

3.4.4 Examining the Effect of Different the Regulatory Restrictions on the Total Risk of Egyptian Banks' Common Stocks

This hypothesis examines the effect of development of regulatory restrictions on the total risk of Egyptian banks' common stocks. The study used Test of Homogeneity of Variances to examine this hypothesis.

Table 12. Test of homogeneity of variances output for banks' common stocks with the developments of regulatory restrictions

\begin{tabular}{ccccc}
\hline & Levene Statistic & df1 & df2 & Sig. \\
\hline RBI & 3.17446 & 1 & 1921 & 0.074956 \\
\hline
\end{tabular}

Source: Statistical Package for the Social Sciences output.

The previous statistical results show that there is no general tendency to change the total risk of banks' common stocks; thus, it can be said that the development of regulatory restrictions has no significant effect on the status of total risk of Egyptian banks' common stocks. 


\section{Conclusions and Recommendations}

\subsection{Conclusions}

- The development of regulatory restrictions and macroeconomic status have meaningful effect on the profitability of banks in Egypt which confirms the validity of the first hypothesis of the study.

- There are two factors that are statistically significant in affecting the return on average equity of banking sector. The first factor is nominated as "Assets and liabilities structure of banking Sector and macroeconomic status"” and it includes a number of variables that are related to the banking sector balance sheet structure and macroeconomic variables. The second factor is nominated as "Financial Markets Performance and Financial Stability" and it includes three variables: stock market return, capital adequacy rate, total public budget deficit growth rate. This conclusion directly agrees with (Bikker \& Hu, 2002) (Naceur \& Kandil, 2013) (Petria et. al., 2015) and indirectly agrees with (Khan et. al.,2015).

The study attributes this conclusion to the effect of macroeconomic variables on the profitability of banks, where during periods of economic prosperity and high rates of economic growth loan defaults declines and profitability of banks tends to increase. In contrary, during periods of economic recession and low rates of economic growth loan defaults increases and the provision for default increases as well and the profitability of banks tends to decrease. This agrees with (De Jonghe \& Öztekin, 2015).

- The development of regulatory restrictions has a positive effect on "interest returns to loan ratio" in Egyptian bank units. This may attribute to the improvement in the process of credit management in bank units with the new set of regulatory restrictions. This finding confirms the validity of the second hypothesis of the study.

- Despite that the development of regulatory restrictions has a short-term negative effect on "net operating income to assets ratio" in Egyptian bank units, where operational expenses tend to increase as a result of the increase in internal audit and risk management processes and capital adequacy provisions and the tendency of different bank units to direct their funds to more liquid and low risk assets, such as treasury bills, in order to support capital adequacy standard; however, this effect turned to be positive in the long-term, where different bank units started to adapt to the new set of regulatory restrictions and improve the return to unit risk resulted from turning to low risk assets. This finding confirms the validity of the third hypothesis of the study.

- The differentiated effect of regulatory restrictions on bank units may lead us to conclude that the characteristics of different bank units, such as bank size, assets quality, management efficiency, effectiveness of bank governance, play a crucial role in determining the impact of development of Basel norms and standards on the profitability of these units. This finding agrees with (Pasiouras \& Kosmidou, 2007) and (Zaky \&Soliman, 2017).

- The returns of Egyptian banks' common stocks have improved with the development of regulatory restrictions. This confirms the validity of the fourth hypothesis of the study.

- The development of regulatory restrictions has differentiated effect on the performance of Egyptian banks' common stocks. On one hand, the hold returns improved with the development of regulatory restrictions (this finding disagrees with Zaky \& Soliman, 2017); however, on the other hand, the development of regulatory restrictions has no significant effect on the status of total risk of Egyptian banks' common stocks. This confirms the invalidity of the fifth hypothesis of the study.

\subsection{Recommendations}

- Where the development of regulatory restrictions and macroeconomic status play a critical role in determining the profitability of bank units and prosperity of banking system in Egypt, then banking system should find an operating framework that simultaneously enhances the macroeconomic status and enables banks to obey to the new set of regulatory restrictions. This framework should be based on two main pillars. 1st Reducing the weight of government securities in the investment portfolio of banks as this type of finance has negative effects on the performance of the economy; 2nd Financing a multiple number of small ventures in different fields, sectors and markets, where financing such small business ventures has a number of positive effects on both the economy as a whole and the returns of bank units' portfolios.

The positive spillovers on the economy include the following points:

- Stimulate economic growth.

- Decrease unemployment rate. 
- Maintain price level stability.

- Decrease poverty rate.

For the banking sector:

- Providing loan for a multiple number of small ventures represent a relatively low risk and more liquid investments (assets) for bank units.

- Growth and prosperity of small ventures through banking finance will improve the degree of financial inclusion and enables for prosperity of the banking sector, in addition to the positive effect of both the decline in unemployment and poverty on the degree of financial inclusion.

- The stock exchange may play an important role in supporting the profitability of banks and capital adequacy requirements. By moving form dividends in cash scheme to dividends in stock scheme the bank will be able to expand its capital and make use of the economies of scale, in addition to the role of new issuing of stocks in expanding the paid-up capital. Moreover, the stock market may play an assessment role, where the performance of banks' stocks in the stock market may reflect the effect of regulatory restrictions on the performance of banks in general and the performance of banks' stock in particular.

\section{References}

Allen, B., Chan, K. K., Milne, A., \& Thomas, S. (2012). Basel III: Is the cure worse than the disease? International Review of Financial Analysis, 25, 159-166. https://doi.org/10.1016/j.irfa.2012.08.004

Athanasoglou, P. P., Brissimis, S. N., \& Delis, M. D. (2008). Bank-specific, industry-specific and macroeconomic determinants of bank profitability. Journal of international financial Markets, Institutions and Money, 18(2), 121-136. https://doi.org/10.1016/j.intfin.2006.07.001

Baba, N., \& Packer, F. (2009). From turmoil to crisis: dislocations in the FX swap market before and after the failure of Lehman Brothers. Journal of International Money and Finance, 28(8), 1350-1374. https://doi.org/10.1016/j.jimonfin.2009.08.003

Bai, J., Krishnamurthy, A., \&Weymuller, C. H. (2018). Measuring liquidity mismatch in the banking sector. The Journal of Finance, 73(1), 51-93. https://doi.org/10.1111/jofi.12591

Basel Committee on Banking Supervision-BCBS. (1988). International Convergence of Capital Measurement and Capital Standards. Retrieved from https://www.bis.org/publ/bcbsc111.pdf

Basel Committee on Banking Supervision-BCBS. (2012). Peer Review of Supervisory Authorities, Implementation of Stress Testing Principles. Bank For International Settlements, April. Retrieved from https://www.bis.org/publ/bcbs218.pdf

Bikker, J. A., \& Hu, H. (2002). Cyclical patterns in profits, provisioning and lending of banks and procyclicality of the new Basel capital requirements. BNL Quarterly Review, 55(221), 143-175. Retrieved from https://ojs.uniroma1.it/index.php/PSLQuarterlyReview/article/view/9907

Curcio, D., \& Hasan, I. (2015). Earnings and capital management and signaling: the use of loan-loss provisions by European banks. The European Journal of Finance, 21(1), 26-50. https://doi.org/10.1080/1351847X.2012.762408

De Jonghe, O., \& Öztekin, Ö. (2015). Bank capital management: International evidence. Journal of Financial Intermediation, 24(2), 154-177. https://doi.org/10.1016/j.jfi.2014.11.005

Dumontaux, N., \& Pop, A. (2013). Understanding the market reaction to shockwaves: Evidence from the failure of Lehman Brothers. Journal of Financial Stability, 9(3), 269-286. https://doi.org/10.1016/j.jfs.2013.04.001

El-Ansary, O., \& Hafez, H. M. (2015). Determinants of Capital Adequacy Ratio: an Empirical Study on Egyptian Banks. Corporate Ownership \& Control, 13(1-10), 1166-1176. http://dx.doi.org/10.22495/cocv13i1c10p4

Fernando, C. S., May, A. D., \& Megginson, W. L. (2012). The value of investment banking relationships: Evidence from the collapse of Lehman Brothers. The Journal of Finance, 67(1), 235-270. https://doi.org/10.1111/j.1540-6261.2011.01711.x

Gambacorta, L., \& Paolo E. M. (2014). Bank heterogeneity and interest rate setting: What lessons have we learned since Lehman Brothers? Journal of Money, Credit and Banking, 46(4), 753-778. https://doi.org/10.1111/jmcb.12124

Gordy, M. B., \& Howells, B. (2006). Procyclicality in Basel II: Can we treat the disease without killing the patient?. Journal of Financial Intermediation, 15(3), 395-417. https://doi.org/10.1016/j.jfi.2005.12.002 
Johnson, M. A., \& Mamun, A. (2012). The failure of Lehman Brothers and its impact on other financial institutions. Applied Financial Economics, 22(5), 375-385. https://doi.org/10.1080/09603107.2011.613762

Khan, Q. M., Kauser, R., \& Abbas, U. (2015). Impact of Bank Specific and Macroeconomic Factors on Banks Profitability: A Study on Banking Sector of Pakistan. Journal of Accounting and Finance in Emerging Economies, 1(2), 99-110. https://doi.org/10.26710/jafee.v1i2.100

Kim, D., \& Song, C. Y. (2017). Bankruptcy of Lehman Brothers: Determinants of Cross-country Impacts on Stock Market Volatility. International Journal of Economics and Financial Issues, 7(3), 210-219. http://dergipark.gov.tr/ijefi/issue/32021/354227

Manish, G. P., \& O'Reilly, C. (2018). Banking regulation, regulatory capture and inequality. Public Choice, 1-20. https://doi.org/10.1007/s11127-018-0501-0

Naceur, S. B., \& Kandil, M. (2009). The impact of capital requirements on banks' cost of intermediation and performance: The case of Egypt. Journal of Economics and Business, 61(1), 70-89. https://doi.org/10.1016/j.jeconbus.2007.12.001

Naceur, S. B., \& Kandil, M. (2013). Has the Basel Capital Requirement Caused Credit Crunch in the Mena Region?. Middle East Development Journal, 5(02), 1-33. https://doi.org/10.1142/S1793812013500144

Ozili, P. K. (2017). Bank profitability and capital regulation: Evidence from listed and non-listed banks in Africa. Journal of African Business, 18(2), 143-168. https://doi.org/10.1080/15228916.2017.1247329

Pasiouras, F., \& Kosmidou, K. (2007). Factors influencing the profitability of domestic and foreign commercial banks in the European Union. Research in International Business and Finance, 21(2), 222-237. https://doi.org/10.1016/j.ribaf.2006.03.007

Pasiouras, F., Tanna, S., \& Zopounidis, C. (2009). The impact of banking regulations on banks' cost and profit efficiency: Cross-country evidence. International Review of Financial Analysis, 18(5), 294-302. https://doi.org/10.1016/j.irfa.2009.07.003

Petria, N., Capraru, B., \& Ihnatov, I. (2015). Determinants of banks' profitability: evidence from EU 27 banking systems. Procedia Economics and Finance, 20, 518-524. https://doi.org/10.1016/S2212-5671(15)00104-5

Prügl, E. (2012) .If Lehman Brothers had been Lehman Sisters...: Gender and myth in the aftermath of the financial crisis. International Political Sociology, $6(1), \quad 21-35$. https://doi.org/10.1111/j.1749-5687.2011.00149.x

Rashid, D., \& Khalid, S. (2017). Impacts of Inflation and Interest Rate Uncertainty on Performance and Solvency of Conventional and Islamic Banks in Pakistan. Journal of Islamic Business and Management, 7(2), 156-177. https://doi.org/10.26501/jibm/2017.0702-002

Rizwan, M. S., Moinuddin, M., L'Huillier, B., \& Ashraf, D. (2018). Does a one-size-fits-all approach to financial regulations alleviate default risk? The case of dual banking systems. Journal of Regulatory Economics, 53(1), 37-74. https://doi.org/10.1007/s11149-017-9340-z

Swamy, V. (2018). Modeling the impact of Basel III regulations on loan demand. Journal of Financial Economic Policy, 10(1), 136-164. https://doi.org/10.1108/JFEP-06-2017-0057

Zaky, A. H. M., \& Soliman, M. M. (2017). The impact of announcement of Basel III on the banking system performance: an empirical research on Egyptian Banking Sector. The Business \& Management Review, 9(2), 165-174. Retrieved from https://search.proquest.com/openview/8ec33cf1d20e2a744059004110267a99/1?pq-origsite=gscholar\&cbl= 2026610

Zheng, C., Rahman, M. M., Begum, M., \& Ashraf, B. N. (2017). Capital regulation, the cost of financial intermediation and bank profitability: Evidence from bangladesh. Journal of Risk and Financial Management, 10(2), 9. http://dx.doi.org/10.3390/jrfm10020009

\section{Copyrights}

Copyright for this article is retained by the author(s), with first publication rights granted to the journal.

This is an open-access article distributed under the terms and conditions of the Creative Commons Attribution license (http://creativecommons.org/licenses/by/4.0/). 